\title{
The Impact of Cultivating Undergraduate Computing Thinking Ability on Computer Course Teaching and Learning FENG QIAN
}

\author{
(Hainan Medical University , Modern Educational Technology Center HaiKou, 571199, \\ China)
}

Keywords: Undergraduates; Computer; Thinking ability; Course teaching; Learning level

\begin{abstract}
With the advent of computer age, people gradually form effective digital information calculation tutorial classes in the process of curriculum teaching, depending on information technology. For modern computer courses' teaching form, we should establish a more effective curriculum reform system to improve students' learning level effects. In the rapid development of modern society, the cultivating of undergraduates thinking calculation ability should be based on modern information education curriculum. This article takes college students' computer courses in the new era as main study object, builds effective teaching facilities, and conducts a comprehensive tutorial analysis according to the existing teaching procedures.

With the development of economic globalization, the application of computer is becoming more and wider in social economy. Therefore, in the teaching of computer courses, we should pay attention to computational thinking ability training, and take it as the main study object. In the process of teaching popularization, form effective information task based on the actual thinking ability training modes. And the cultivation of students' comprehensive quality should be analyzed from the following points.
\end{abstract}

\section{THE PRESENT TEACHING STATUS OF INFORMATION COURSES IN OUR COUNTRY}

Digital teaching form classes have become common in schools. As a new curriculum type, its influence on the innovation ability of students has a better promoting role. From the school request, the operation and application of curriculum content also basically conform to the corresponding computer operation process, and have a good role in promoting system design in the future. On the design capacity requirements for the media creation, make effective information customers design according to the design of course standard, and on the basis of analysis ability of the students, complete a comprehensive information construction. And according to the teaching reform, do the corresponding education reform.

In the rapid development of modern society, make the reform and analysis according to the practice courses indicators of the undergraduates, and further analyze based on digital multimedia course form, make technological display construction on the basis of focus training effect of application ability, which has good role in promoting the construction of digital haunted multimedia course education. In undergraduate course teaching, for example, make a positive course form to deal with student's lack of interest, construct skill knowledge conforming to the teaching content, and set up constructive rules on theoretical knowledge. Through effective education structure construction, finally realize the compatibility construction of the whole information.

For students' personal skills mastering, construct comprehensive infrastructure of the whole ability.

\section{Multimedia COURSE CONSTRUCTION IN COURSE DESIGN}

In undergraduate education training, according to cultivation goal, form a comprehensive training on students' ability, and according to students' comprehensive quality training, strengthen knowledge ability. In basic course teaching, digital multimedia teaching is more important, mainly aiming at course complying procedure. To content social economic development structure form, carry out a variety of information construction through communication ways, so as to further achieve the effective development of the economy. In digital multimedia course teaching, we should 
teach not only as a form. Digital teaching mode is a kind of thinking reform of the existing teaching mode. It is a fundamental important measure to solve the existing problems.

The new curriculum education form can improve students thinking ability in computer information course on application computational thinking mode, and eventually improve students' comprehensive quality and ability. In course practice, finally realize the overall comprehensive quality promotion through innovation ability raise.

Facing modern curriculum reform progress, in the cultivation of thinking calculation, effective thinking innovation capability construction needs to be made from international status. Through international code conduct training in the new century, realize the overall computing information ability training, and make further basic concept ascension on the basis of scientific shape structure of computers. In the process of teaching, in view of multimedia education form, develop students' open thinking so as to complete the development and construction of students' thinking abstraction.

In addition, in training of thinking ability, computing thinking ability shall be determined based on comprehensive information, and finally realize the improvement of innovative thinking mode. This has a good role in promoting the future courses popularization and other aspects. By students' thinking skills training of higher institutions, improve the effective extension on computing power consciousness.

\section{HOW TO BETTER DEVELOP STUDENTS' THINKING CONSCIOUSNESS}

With the reform of modern university system, the training of student ability should also pay attention to students' calculation ability cultivation. Due to the acceleration of modernization, people's computing power is greatly declining, which reduces the training of students' calculation ability. To solve the problem of actual operation ability, in the teaching of media information, strengthen the practice ability in this regard to effectively improve the thinking ability of students. In promoting the leading information, carry out the following several aspects.

A. Strengthen targeted system measures in digital multimedia teaching

In digital multimedia teaching, the key of computational thinking cultivation lies in basic tutorial of the course. How to improve the calculation thinking is taken as the nature study object, and finally realize computational thinking training on the course. For how to improve the goal of teaching, in practice, strengthen the unity adjustment of teaching target, and improve their cognition on the basis of constantly present study and communication in the process of teaching, so as to complete the effective teaching mode creation. In creating, we shall conduct the reform in view of the following tips.

First, on project arrangement, accord with industry practice, do regular discussion exchange, and increase students' computational abstract thinking ability through effective training model. To achieve effective education construction mechanism reform, complete the effective adjustment of the form through teachers' professional arrangement, and comprehensively arrange according to the information. Finally on the basis of the subject adjustment, realize the teaching reform of students' thinking abilities.

Second, seize the professional market mode for effective thinking mode cultivation. Through the existing digital media teaching construction, realize students' ability training in the professional background, and on the basis of digital multimedia teaching reform, realize teachers' curriculum reform, form a reasonable teaching group, and cultivate the students thinking ability in professional orientation. In this way, further promote students' comprehensive cognitive analysis on professional calculation form.

B. In teaching content, achieve enlightenment through the reform of teaching content customization

In modern higher education teaching, media teaching mode is the main body of the teaching content. And most of the teaching content has the cultivation of thinking ability, and is able to provide a more classic case analysis course. And through this understanding of class form, according to student's reserve nature, eventually realize the significance of courses.

C. The design of the experiment contents should have certain interest comprehension 
In teaching for many years, the author found that in a boring teaching classroom, even though the interpretation of knowledge has a very important relevance to the future employment purpose, in the actual use of the course, still we cannot make effective exercise education.

From students' point of view, fun comprehensive subject can be more eye-catching, which is their demanding course form. This topic can better stimulate the development of students' creative thinking. On the answer to abstract problem, form the lecture through new way of thinking, which can better promote students on the state of mind to accept such courses. In addition, in multimedia teaching, the openness and sharing of teaching resources also further promote the cognitive training of foundation and application, which has played a decisive role.

\section{Learning course reform in university teaching}

In current university teaching, the existing learning course reform should be adjusted, not only for effective reform on computer science, also in comprehensive effective reform on social development. Irrational professional cognition, in the innovation, should strengthen the ability of college students on computational thinking build and it would play a good role in promoting the structure adjustment in the future and social development, and so on.

For non-computer professional teaching level of computing education, we have a university compulsory course "Computer Network". We should also grasp the course of implementation, and shall keep the original basic course of higher mathematics. From the perspective of teaching content, strengthen teaching method construction, through effective learning method, achieve the education of students' knowledge acquisition form, improve the students' self-study ability, and supervise the initiative of students.

In teaching of acceptance, reform should be adjusted. From the objective perspective, the evaluation of teaching quality problem determines the appraisal system's main morphological structure. And the traditional appraisal system, to a great extent, does not take into account the students' mastery of skills. To better implement the students mastering in the course, in the process of curriculum evaluation, strengthen usual classroom course form research, and strengthen the practice of students' research. Teachers' rating system is one of the final grade examination standard evaluations. Through various appraisal system adjustments, eventually make the final score of students' school year knowledge learning, which ensures the learning effectiveness.

In the teaching reform, we should encourage self-adjusting in knowledge innovation ability to motivate students, and by inspiring the students' seeking knowledge desire, truly achieve effective self-learning form and promote the effectiveness of studying basic knowledge. The students' individual innovation ability adjustment can greatly promote the students' individual ability.

\section{CONCLUSION}

In modern higher education course teaching, we should not abandon the teaching insist on personal ability training in following up the pace of social development. Talent cultivation in universities is in the attention from all walks of life in the society. On the cultivation of talents in the process, student calculation thinking ability cultivation has become the common defect of modern college students. Now information technology can be information supplement, but fast reaction of calculation thinking is also the effectiveness building of the space thinking ability, which has good leading role for future information construction within the scope of information certification. In today's China, we lack this ability training, and along with the rapid development of computer technology in the future, it also will be a great effect on the cultivation of thinking ability. In project design, we should consider these problems.

\section{REFERENCES}

[1] Zhao Yijin. Computing thinking ability training study in digital media [J]. Computer CD Software and Applications, 2013, (5): 76-77.

[2] Wang Huangmao. Cultivating high school students meta-cognitive ability in mathematics teaching exploration [D]. Zhejiang Normal University, 2010. 
[3] Li Zhenda. The application study of collaborative learning based on cloud computing in secondary vocational school computer course [D]. Guangdong Technology Normal University, 2013.

[4] Yang Zhihe. Case teaching and its practice in computer basic course [J]. Journal of Education Informatization, 2005, (5) : 70-71.

[5] Li Yichen, Liu Liwei, Ma Ruisheng. Tissue embryology teaching mode under network environment [J]. Journal of Anatomy in Sichuan, 2001, 9 (2) : 80-81.

[6] Wang Ying. ASP.NET application design teaching practice based on integrated case [C] 2011 Beijing fashion institute disciplines profession construction compiled research papers. 2011:202-204.

[7] Yang Hui. College students information literacy training mode research---- Based on Big6 computer basic course teaching practice [D]. Central China Normal University, 2007. 